\title{
The Impact of Nursery on Children in Terms of Learning and Social Behaviors (The Motivation for Learning and Social Behaviors after Joining the Primary Grades at the Elementary Level)
}

Badr MM*, Gamdi SA, Hakeem S, Almansour A, Algamdi N and Albogami A

Statistics Department, Faculty of Science for Girls, King Abdulaziz University, Jeddah, Saudi Arabia

*Corresponding author: Badr MM, Statistics Department, Faculty of Science for Girls, King Abdulaziz University, 21577, P. O. Box-70973, Jeddah, Saudi Arabia, Tel: 0504621860,012605230; E-mail: mbador@kau.edu.sa

Received date: June 14, 2016; Accepted date: July 29, 2016; Published date: August 04, 2016

Copyright: () 2016 Badr MM, et al. This is an open-access article distributed under the terms of the Creative Commons Attribution License, which permits unrestricted use, distribution, and reproduction in any medium, provided the original author and source are credited.

\begin{abstract}
The kindergarten is the most important and most fertile stages of education and represent an educational place in the educational levels because it is considered a strong foundation and the base for all levels of education, especially the early years of basic education, it is a preliminary stage of the stages of primary education, a strong bridge to transport the child from the limited his world to the school environment including where the topics of study and educational programs of different social relations, from this point we study this subject for the population.
\end{abstract}

Keywords: Kindergartens; Behavioral; Acquisition; Development; Analysis; Measurement

\section{Introduction}

The Nations auspices for their children and direct their growth towards the educational goals sets is an important measure of the progress and advancement of civilization and culture, and their care and upbringing and education a fundamental duty of every society is looking towards the advancement and progress. The kindergarten is the important stages of education in an effective education system, which is the foundation phase in building the character and future of the child and has a decisive role in the development of talents and expands his mind. A kindergarten educational became necessary learning stage in this age and stand-alone educational which has its philosophy, objectives of the educational curriculum, learning methods, diverse games, their buildings, qualified staff educationally and psychologically to deal with kindergarten children consciously and desire continuous activity. These are some of the previous studies that show that:

- A Master study, Khalid Hassan Ali, entitled (kindergarten management and supervision through the study of the reality of the kindergarten in the city of Irbid, Jordan).

- A Master study, Rafah Mohammed bin Laden, entitled (administration nursery school and kindergarten in the city of Jeddah).

- PhD study, Sabah Mohammed Saleh Khuraiji, entitled (Study of the use of toys in kindergarten).

\section{The Emergence of Kindergarten}

Kindergarten is an educational and social institutions attended by the children to have a deal of care and education and also called (nursery schools or children's homes or preschool or day care centers). The role of kindergarten is a variety of diverse covers care needs of the child and meet their needs in different age periods since they are born until the last stage where they stand on the threshold of entering into primary formal education stage, the system is based on two things, the first definition of the child broader community of which return the improves their mixing skills and secondary is the education of the child through play.

\section{The concept of kindergarten}

It is the stage of pre-primary education and is a non-mandatory stage the child is committed to religious care and physical, intellectual and social.

\section{Educational goals in kindergarten}

Maintain the encroachment of child and care and develop of moral, mental and physical in safe and normal conditions, responsive to the requirements of Islam and to make him comfort with school environment and prepare him for school life and develop of the child's ability to self-discipline of the behavior and control his emotions and create a child of social life based on respect other party and to cooperate with him, the develop of a child's ability to solve problems.

Provide a rich of correct expressions and easy information appropriate to his age and relating to what surrounds him, encourage his creative activity and pledged aesthetic taste and the opportunity in front of vitality for the start of guided way and the develop of child's self-confidence as a human who has abilities and features.

\section{The emergence of kindergartens in the world}

It was in the early 18th century where the centers were set up to provide religious education and health protection for the young in Britain, and established in the early 19th century nurseries in Britain, Germany and Italy [1].

\section{The emergence of kindergartens in the Saudi Arabia}

The first public kindergarten in the Kingdom in 1395 in Mecca was established, and after the success of the experiment Presidency of Girls Education began the opening of the kindergarten year after year [2]. 
Citation: Badr MM, Gamdi SA, Hakeem S, Almansour A, Algamdi N, et al. (2016) The Impact of Nursery on Children in Terms of Learning and Social Behaviors (The Motivation for Learning and Social Behaviors after Joining the Primary Grades at the Elementary Level). Arts Social Sci J 7: 206. doi:10.4172/2151-6200.1000206

Page 2 of 9

Those who oversaw the creation and development of kindergartens in the Saudi Arabia:

1) Private Sector 2) The Ministry of Labor and Social Affairs 3) The Ministry of Education's [2].

Famous speakers in kindergarten:

Imam al-Ghazali, Ibn Khaldun, Rousseau, Bstwazzy, Vrobl, Margit and Macmillan, Mentouri, John Dewey, Piaget and Komenus [3].

\section{The Process of Education in Kindergarten}

The kindergarten task is not confined to the educational side only, but is seeking to achieve integration in the child's personality and sponsorship growth and satisfy his need for knowledge, creativity and independence and growth in the emotional, moral, religious, linguistic and sensory areas, as well as prepare him for the primary stage and kindergartens has a great importance in shaping personality of the child through several factors: Physical factors, genetics, maturity, culture, family, the environment and education [4].

\section{The importance of preparation of the child to the stage of school}

The child's transition from early childhood to school kindergarten is a huge milestone in the transition of the child's life which requires longer and a good preparation, also he becomes responsible for his actions and behavior by follow the rules and laws may not impose before, this responsibility lies all on family and kindergarten teacher [5].

\section{Kindergarten teacher career}

Kindergarten teacher is a professional educator in the field of childrearing in pre-primary school and is working to protect, raise children, proper health care and contribute significantly to the personal development of the child comprehensive development physically, mentally, emotionally, socially, linguistically, behaviorally and religiously [6].

\section{The role of kindergarten teacher}

Take a mother place, Education, she is representative of the values of society - Channel link between home and kindergarten - is responsible for classroom management and the maintenance of its system - a teacher and student at the same time - director psychological and educational [7].

\section{Conditions to be met by the kindergarten teacher}

She has a genuine desire to deal with children, balance of emotional, ability to establish positive social relationships, a healthy body and senses, good language and do not suffer from speech problems, be kind to be a model for others and a good degree of intelligence and intellectual flexibility [8].

\section{The teacher in kindergarten main tasks}

It could be classified in three main tasks:

First: the role of the teacher about the child in kindergarten.

Second: the role about her-self.
Third: the role towards achieving the requirements of society [9].

\section{Skills that show whether the child is ready to enter kindergarten}

First, social and emotional maturity and there are signs:

- Independence through afford some personal obligations, such as wearing clothes and undressed alone, or re-purpose into place after the completion of use, go to the bathroom alone.

- The ability to control some of his actions, or at least try to do so.

- The ability to get away from his mother for a sometime during daytime.

- Ability to express his needs appropriately socially.

- The ability to follow certain rules and behaviors that fit the kindergarten system.

- Ability to deal with strangers.

Second: the desire to learn and is determined by the following:

- Curiosity about his world, and how things work.

- The use of words and numbers that shows versatility in the count.

- Installation of blocks and try to distinguish between colors.

- Discover the world of play by playing with others or alone [5]

Some basic practices that must be followed by the mother to prepare her child to enter kindergarten:

Language skills - movement skills - independence - social skills [5].

\section{The importance of partnership between kindergarten and the family}

By providing a bridge of confidence and understanding of the role and responsibility of kindergartens and activating the role of parents to provide opportunities for dialogue in a child's personality development gradually and firming up [5].

Activating the partnership between kindergarten and the family through the following.

- In a meeting with the new parents.

- Individual meeting (mother and teacher).

- The bilateral meeting (between the teacher and the mother and her child) [5].

\section{Basic rules for raising a child in the home}

Model, follow-up, love, discipline, reward and punishment, participation and community spirit, connecting values, the language of dialogue, affection [10].

Some of the problems may face the child when joining the kindergarten for the first time:

Acclimatization, spoiled child, child with concern the separation [5].

\section{Kindergarten Curriculum in Saudi Arabia}

Early childhood of human life is critical, The brain grows at that point at a higher rate than the growth of any other part of the human body, and the first years of a child's life is very crucial years in the development of the brain, and the curriculum content provided to the child of is paramount importance as a connecting liaison between the 
Citation: Badr MM, Gamdi SA, Hakeem S, Almansour A, Algamdi N, et al. (2016) The Impact of Nursery on Children in Terms of Learning and Social Behaviors (The Motivation for Learning and Social Behaviors after Joining the Primary Grades at the Elementary Level). Arts Social Sci J 7: 206. doi:10.4172/2151-6200.1000206

Page 3 of 9

child and teacher, because it contains a set of experiences and cognitive activities (informational content), and skill (psychological dynamic content), and emotional (the emotional content) and there are two types of organizations of curriculum content: logical and psychological.

\section{The curriculum's content selection conditions and criteria}

Content is linked to the objectives and be honest and significant and there is a balance between comprehensiveness and depth of content and content takes into account the tendencies, needs and abilities of the child also the content is linked to the community in which the child lives.

Appropriate ways to choose the curriculum and content in kindergarten:

- The curriculum and stages of growth.

- The curriculum and inclusive growth.

- The motivation and curriculum.

- The curriculum and the children readiness to learn.

- The most important principles of learning and its relationship to the curriculum.

The characteristics to be considered in the daily program for kindergartens:

- Regularity and consistency in the sequence of periods.

- Diversity in ways of learning.

- Meet the needs of children in this age.

- The principle of self-learning.

- Principle of freedom of choice and learn responsibility.

\section{Daily program periods in kindergarten depends on}

Episode, free play outside, a meal time, self-employment in the Chiefs period, the period of the last meeting.

\section{Learning modules}

Modules contain the kindergarten curriculum in seven books. The first book is the core curriculum the second book is the summary educational units (clothing, Mates and family, my safety and my health, my book) and the remaining five books contain detailed educational units (water, sand, food, housing, hands).

\section{Learning corners in the classroom}

Period is based on the application of the principle of self-education, and the some corners in the class (home, construction and demolition, technical, Cognitive, discovery, planning, library corner).

\section{Statistical Analysis}

The impact of nurseries for children in terms of (the motivation for learning and behavior after their enrollment in primary grades in elementary school) $[11,12]$.

Due to the importance of this subject we did a questionnaire includes the following topics:

- First: the importance of kindergarten.

- Second: Family awareness of kindergarten importance.

- Third: the impact of kindergarten on children (the acquisition of educational and behavioral skills).
- Fourth: The role of teacher in kindergarten.

We have designed the questionnaire in the final image attachment.

The exploratory sample of work to make sure the integrity of the survey questionnaire and then publish in social media, we got a sample of 431 obtained in the manner available.

We use statistical analysis (SPSS) program in data analysis.

We used the method Likert scale because it allows more credibility of the individuals who fill out the questionnaire. We look for the impact of the nursery on the children in terms of (the motivation for learning and social behaviors after their enrollment in grades primary to primary school) were selected following notations options: Strongly Agree 5, agree 4, neutral 3, I do not agree 4 strongly disagree 1 . Results as follows:

First: We note that the average score of the first is equal to 4.197 and this shows by Likert scale that mothers, agreed on the $(\mathrm{OK})$ as regards of (the importance of kindergarten in general on a child in kindergarten and its impact later on joining the school) (Figure 1).

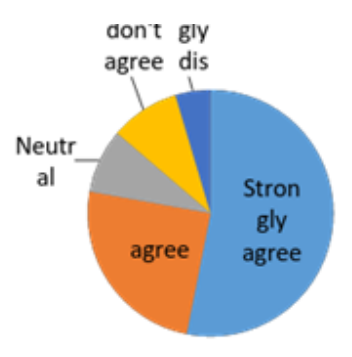

Figure 1: Diagram shows the importance of the opinions ratios in kindergarten (generally on a child in kindergarten and the effect this phases later on joining the school).

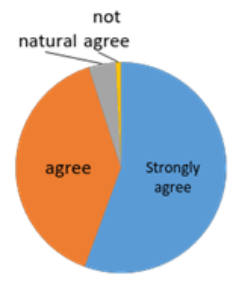

Figure 2: Diagram shows the view of the awareness of parents' ratios of kindergarten stage for the first stages of the initial.

Second: We note that the average result of the second is equal to 4.5 and this shows by Likert scale that all of them mothers (strongly disagree) in the consciousness of parents kindergarten stage for the first stages of the primary (Figure 2).

Third: We note that the average score of the third is equal to 4.39 and this shows by Likert scale that all of them mothers (strongly disagree) on the impact of kindergarten children on the one hand (the acquisition of educational and behavioral skills) (Figure 3). 
Citation: Badr MM, Gamdi SA, Hakeem S, Almansour A, Algamdi N, et al. (2016) The Impact of Nursery on Children in Terms of Learning and Social Behaviors (The Motivation for Learning and Social Behaviors after Joining the Primary Grades at the Elementary Level). Arts Social Sci J 7: 206. doi:10.4172/2151-6200.1000206

Page 4 of 9

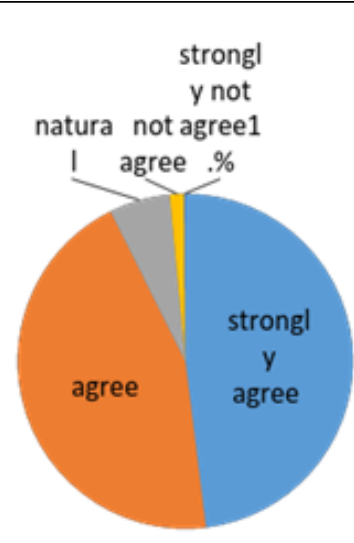

Figure 3: Diagram shows the view of the impact of kindergarten children rates on the one hand (the acquisition of educational and behavioral skills).

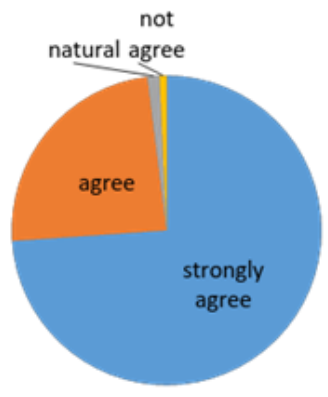

Figure 4: Diagram opinion ratios clarify the role of teacher in kindergarten.

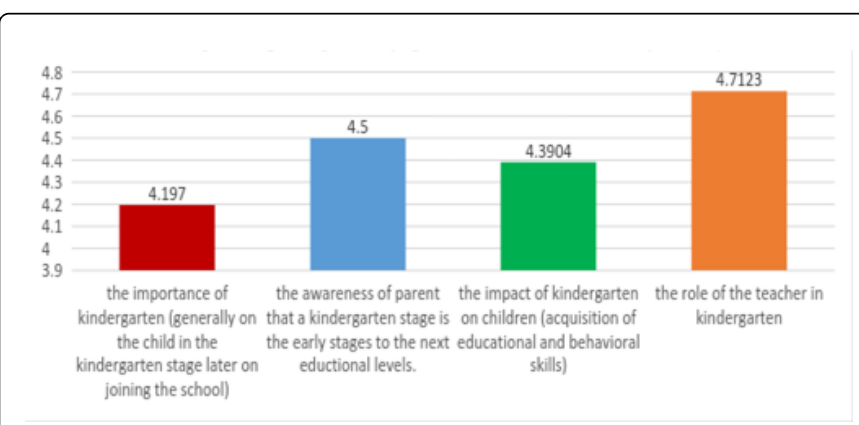

Figure 5: Diagram shows the average opinions affect nurseries on children (the motivation for learning and social behaviors after joining the primary grades at the elementary level).

Fourth: The average fourth is equal to 4.71 and this shows by Likert scale that all of mothers (strongly disagree) for the role of the teacher in kindergarten (Figure 4).

The Figure 5 shows that the highest value for the average consensus was (4.7) for the fourth (the role of the teacher in kindergarten), followed by the average second (the awareness of parents kindergarten stage the first stages of the first rows step) was (4.5) and then average the third (MADA the effect of kindergarten children on the one hand, the acquisition of educational and behavioral skills) were (4.4) and the lowest average was for the first (the importance of kindergarten in general on the child in the kindergarten stage later on joining the school) was (4.2).

\section{Study of statistical hypotheses}

In this section we'll examine statistical hypotheses that were built on the basis of the study.

First, the study of the relationship between the importance of kindergarten in general on a child in kindergarten later on joining the school and kindergarten helping to raise their children in favor of the emergence of various aspects (social-psychological - behavioral) to prepare them for school.

Suppose that Null hypothesis H0: No relationship between the importance of kindergarten in general on the child later on joining the school and the contribution of the kindergarten to help raise the child origination valid in all respects (social-psychological-behavioral) to prepare them for school [13].

Alternative hypothesis H1: There is a relationship between the importance of kindergarten in general on the child later on joining the school and the contribution of the kindergarten to help raise the child origination valid in all respects (social-psychological-behavioral) to prepare them for school.

We used the Pearson correlation coefficient after converting the sample data to the amount of evidence.

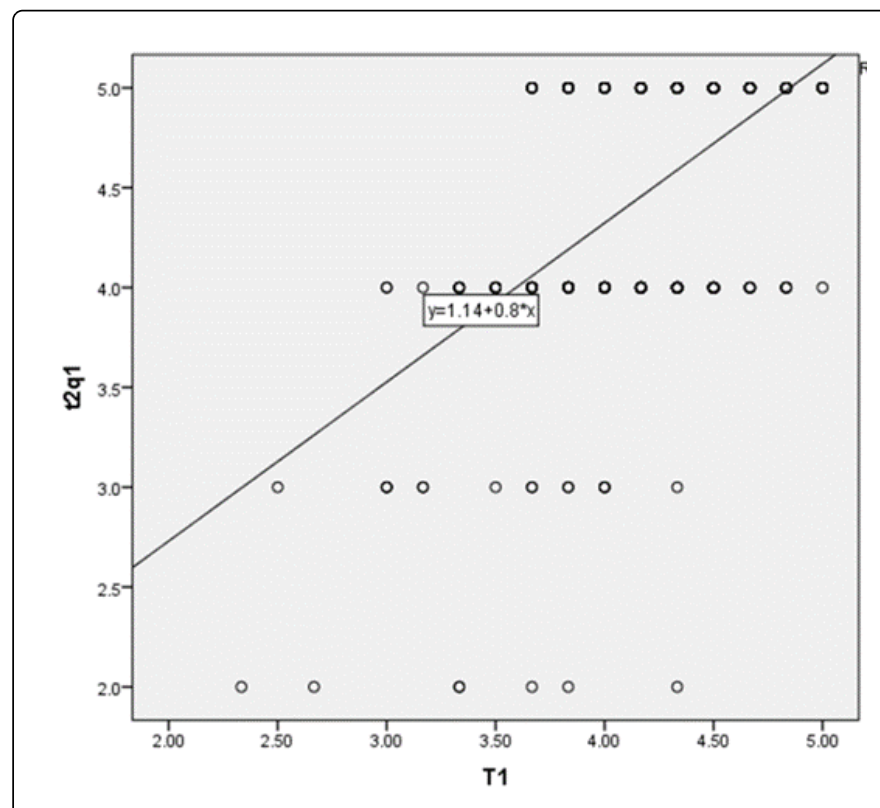

Figure 6: Suffusion and regression linear equation.

Figure 6 shows both the suffusion as well as regression linear equation (coefficient $\mathrm{x}$ ) the offer or indicate the presence of extrusive correlation between both (T1, t2q1).

Table 1 illustrated, there is a strong correlation is somewhat of a relationship (T1, t2q1) where the Pearson correlation coefficient (0.53). 
Citation: Badr MM, Gamdi SA, Hakeem S, Almansour A, Algamdi N, et al. (2016) The Impact of Nursery on Children in Terms of Learning and Social Behaviors (The Motivation for Learning and Social Behaviors after Joining the Primary Grades at the Elementary Level). Arts Social Sci J 7: 206. doi:10.4172/2151-6200.1000206

Page 5 of 9

This means that increasing awareness of parent's contribution kindergarten upbringing of children origination valid in all respects, the greater the importance of kindergarten the child later attachable school.

\begin{tabular}{|c|c|c|c|}
\hline \multicolumn{4}{|c|}{ Correlations } \\
\hline & & T1 & t2q1 \\
\hline \multirow[b]{3}{*}{ T1 } & Pearson Correlation & 1 & 0.528 \\
\hline & Sig. (2-tailed) & & 0 \\
\hline & $N$ & 431 & 431 \\
\hline \multirow[b]{3}{*}{$\mathrm{t} 2 \mathrm{q} 1$} & Pearson Correlation & 0.528 & 1 \\
\hline & Sig. (2-tailed) & 0 & \\
\hline & $\mathrm{N}$ & 431 & 431 \\
\hline
\end{tabular}

Table 1: Shows the relationship between (T1), (t2q1).

And also it shows through the Table 6 that, sig $=0.000$ less than $\alpha=$ 0.05 . This shows there is a high statistical significance, leading to the imposition of nothingness and the acceptance of the hypothesis rejected the alternative and this shows that there is a relationship between the importance of kindergarten in general on the child in kindergarten later on joining the school and kindergarten contribution in helping to raise their children in favor of the emergence of various aspects (social-psychological - behavioral) to prepare them for school.

Second, the study of the relationship between the effect of kindergarten on children (the acquisition of educational and behavioral skills) and the enrollment of child kindergartens eliminates the fear of school and reduce the child's parents and family relation.

\section{Suppose that:}

Null hypothesis H0: There is no relationship between the impact of kindergarten children, the acquisition of skills (behavioral and educational) and enroll a child in kindergarten eliminates the fear of school and reducing child's parents and family relation.

Alternative hypothesis H1: There is a relationship between the impact of kindergarten children on the one hand, the acquisition of skills (behavioral and educational) and enroll a child in kindergarten eliminates the fear of school and educing child's parents and family relation.

Figure 7 shows the suffusion as well as regression linear equation (coefficient $\mathrm{x}$ ) the offer or indicate the presence of extrusive correlation between both (T3, t2q5).

Table 2 illustrated that there is a strong correlation to some extent between (T3, t2q5) where the Pearson correlation coefficient (0.54).

This means that whenever kindergartens effect increased over the children in terms of acquisition of educational and behavioral skills has increased from kindergarten task of elimination on the child's fears and reduces its association with parents.

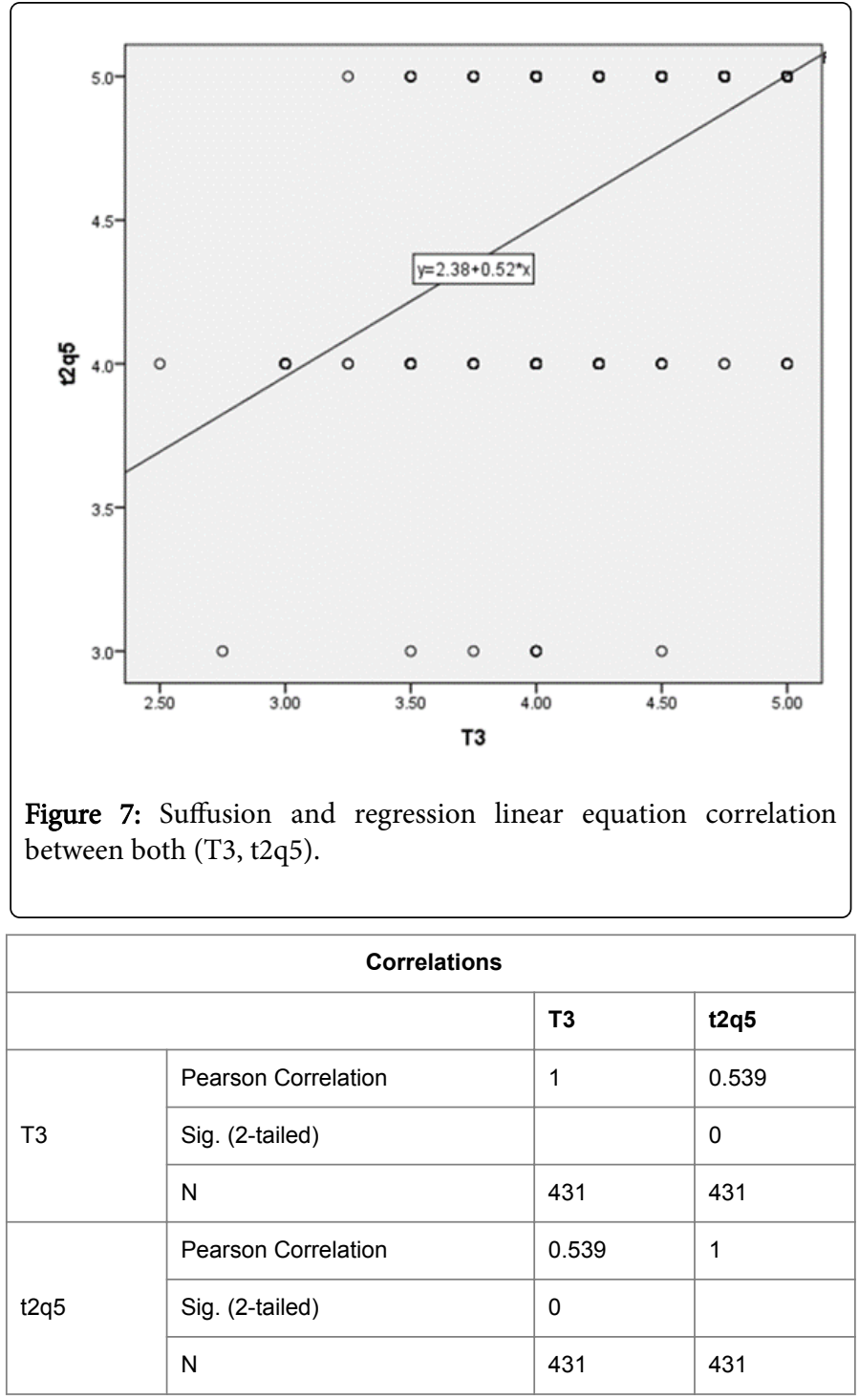

Table 2: The relationship between (T3), (t2q5).

It also shows through the Table 2, that: sig $=0.000$ less than $\alpha=0.05$. This shows there is a high statistical significance, which leads us to reject the null hypothesis and accept the alternative hypothesis which is] that there is a relationship between the impact of kindergartens on the children in terms of (the acquisition of skills educational and behavioral (and the enrollment of a child kindergartens eliminates the fear of school and reduce the child's parents and family relation.

Third: The study of the relationship between the awareness of parents of the importance of kindergarten for the first stages of the primary rows step and the contribution of kindergartens in satisfying the child's need for knowledge, creativity and social adjustment.

Suppose that Null hypothesis H0: There is no relationship between people's awareness of the importance of kindergarten for the first stages of the primary rows step and the contribution of kindergartens in satisfying the child need for knowledge and innovation and social adjustment. 
Citation: Badr MM, Gamdi SA, Hakeem S, Almansour A, Algamdi N, et al. (2016) The Impact of Nursery on Children in Terms of Learning and Social Behaviors (The Motivation for Learning and Social Behaviors after Joining the Primary Grades at the Elementary Level). Arts Social Sci J 7: 206. doi:10.4172/2151-6200.1000206

Page 6 of 9

Alternative hypothesis H1: There is a relationship between people's awareness of the importance of kindergarten for the first stages of the primary rows step and the contribution of kindergartens in satisfying the child need for knowledge and innovation and social adjustment.

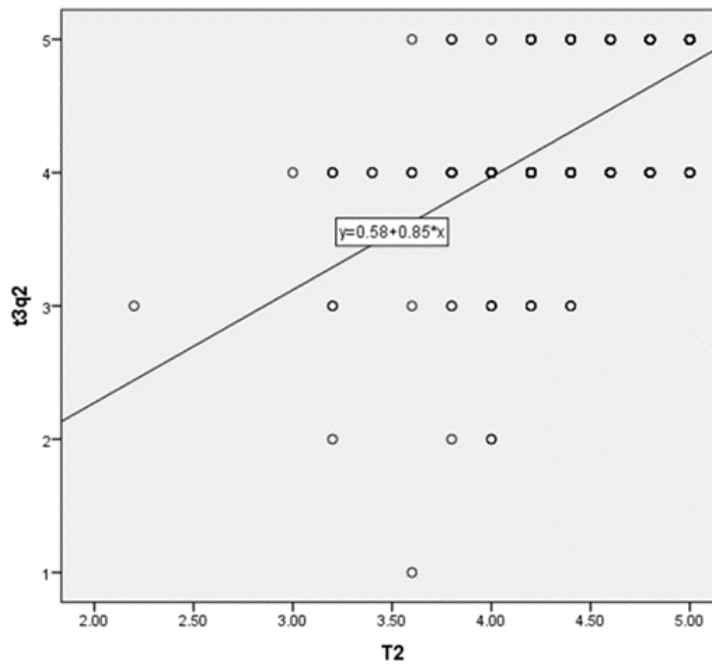

Figure 8: Suffusion and regression linear equation correlation between both (T2, t3q2).

Figure 8 shows that the suffusion as well as regression linear equation (coefficient $\mathrm{x}$ ) the offer or indicate the presence of extrusive correlation between both (T2, t3q2).

\begin{tabular}{|c|c|c|c|}
\hline \multicolumn{4}{|c|}{ Correlations } \\
\hline & & T2 & t3q2 \\
\hline \multirow{3}{*}{ T2 } & Pearson Correlation & 1 & 0.621 \\
\hline & Sig. (2-tailed) & & 0 \\
\hline & $\mathrm{N}$ & 431 & 431 \\
\hline \multirow{3}{*}{ t3q2 } & Pearson Correlation & 0.621 & 1 \\
\hline & Sig. (2-tailed) & 0 & \\
\hline & $N$ & 431 & 431 \\
\hline
\end{tabular}

Table 3: Shows the relationship between (T2), (t3q2).

Table 3 illustrated, there is a strong correlation to some extent between $(\mathrm{T} 2, \mathrm{t} 3 \mathrm{q} 2)$ where the Pearson correlation coefficient $(0.621)$ This means that the more awareness of parents has increased the importance of kindergarten first stages of the primary rows step whenever the contribution of kindergartens has increased to satisfying child's need for knowledge, creativity and social adjustment.

It also shows through the Table 3, that: sig $=0.000$ less than $\alpha=0.05$. This shows there is a high statistical significance, which leads us to reject the null hypothesis and accept the alternative hypothesis which is a relationship between the awareness of parents of the importance of kindergarten first stages of the primary rows step and the contribution of kindergartens in satisfying the child need to know, creativity and social adjustment.
Fourth: The study of the existence of the effect of the educational level of the mother and the awareness of locals' kindergarten stage:

Suppose that Null hypothesis H0: No effect between educational level of the mother and the awareness of parents' kindergarten stage.

Alternative hypothesis $\mathrm{H} 1$ : There is no impact between educational level of the mother and the awareness of parents' kindergarten stage for this purpose; we used one-way analysis of variance to deal with hypotheses in order to complete the following conditions:

First, the data follows a normal distribution, and for that we have made the following:

- Assumptions Null hypothesis H0: data do not follow a normal distribution.

- Alternative hypothesis H1: data follow a normal distribution.

\begin{tabular}{|l|l|l|l|l|l|l|}
\hline \multicolumn{5}{|c|}{ Tests of Normality } \\
\hline & \multicolumn{3}{|c|}{ Kolmogorov-Smirnova } & \multicolumn{3}{l|}{ Shapiro-Wilk } \\
\cline { 2 - 7 } & Statistic & df & Sig. & $\begin{array}{l}\text { Statisti } \\
\text { c }\end{array}$ & df & Sig. \\
\hline $\begin{array}{l}\text { Educational } \\
\text { level of the } \\
\text { mother }\end{array}$ & 0.383 & 430 & 0 & 0.746 & 430 & 0 \\
\hline T2 & 0.16 & 430 & 0 & 0.889 & 430 & 0 \\
\hline
\end{tabular}

Table 4: The normal distribution test.

We conclude by the Table 4 to Sig $=0.000$ less than $\alpha=0.05$ and thus reject the null hypothesis and accept the alternative hypothesis is that the data follow a normal distribution (the first condition has been achieved).

Second: Independence and look for the independence of the data.

- Null hypothesis H0: The first variable is not independent of the second variable.

- Alternative H1: The first variable independently of the second variable.

\begin{tabular}{|l|l|l|l|}
\hline \multicolumn{3}{|c|}{ Chi-Square Tests } \\
\hline & Value & df & $\begin{array}{l}\text { Asymp. Sig. } \\
\text { (2-sided) }\end{array}$ \\
\hline $\begin{array}{l}\text { Pearson Chi- } \\
\text { Square }\end{array}$ & $59.088 \mathrm{a}$ & 33 & 0.003 \\
\hline Likelihood Ratio & 62.466 & 33 & 0.001 \\
\hline $\begin{array}{l}\text { Linear-by-Linear } \\
\text { Association }\end{array}$ & 1.872 & 1 & 0.171 \\
\hline N of Valid Cases & 430 & & \\
\hline
\end{tabular}

Table 5: Chi-Square independent.

We find through the Table 5 to Sig $=0.003$ less than $\alpha=0.05$ and thus reject the null hypothesis and accept the alternative hypothesis is that the first variable independently of the second variable.

Third, the data close: As we have encodes (encoding) data that means it digital (amount). 
Citation: Badr MM, Gamdi SA, Hakeem S, Almansour A, Algamdi N, et al. (2016) The Impact of Nursery on Children in Terms of Learning and Social Behaviors (The Motivation for Learning and Social Behaviors after Joining the Primary Grades at the Elementary Level). Arts Social Sci J 7: 206. doi:10.4172/2151-6200.1000206

Page 7 of 9

Fourth: Random, since the data gathered through appropriate random ways. Thus we can use analysis of variance to study the presence of the impact between the level of the mother and the awareness of parents of the importance of teaching kindergarten as a first step.

Fifth: Homogeneity.

Null hypothesis H0: Variations communities drawn them equal samples (no smoothing).

Alternative hypothesis H1: Variations communities drawn samples of which is equal (no smoothing).

\begin{tabular}{|l|l|l|l|}
\hline \multicolumn{4}{|l|}{ Test of Homogeneity of Variances } \\
\hline T2 & df1 & df2 & Sig. \\
\hline $\begin{array}{l}\text { Levene } \\
\text { Statistic }\end{array}$ & 3 & 426 & 0.003 \\
\hline 4.666 & & & \\
\hline
\end{tabular}

Table 6: Homogeneity.

The Table 6 shows Sig $=0.003$ less than $\alpha=0.05$ and thus reject the null hypothesis and accept the alternative hypothesis which has no homogeneity Resort in the absence of the conditions on the society in which they pulled him into the sample nonparametric statistical methods are met, we using Kruskal-Wallis test. This test was chosen because it is an alternative to non-parametric to test one-way analysis of variance to measure the impact of the mother's education level of parents are aware of kindergarten stage a first step in the early stages (Table 7).

\begin{tabular}{|l|l|l|l|}
\hline & Educational level of the mother & N & Mean Rank \\
\hline \multirow{3}{*}{ T2 } & Medium or less & 16 & 102.78 \\
\cline { 2 - 4 } & secondary & 90 & 236.63 \\
\cline { 2 - 4 } & Academic & 291 & 212.66 \\
\cline { 2 - 4 } & Collectors and older & 33 & 237.61 \\
\cline { 2 - 4 } & Total & 430 & \\
\hline
\end{tabular}

Table 7: Average grade.

\begin{tabular}{|l|l|}
\hline \multicolumn{2}{|l|}{ Test Statisticsa,b } \\
\hline & T2 \\
\hline Chi-Square & 17.536 \\
\hline df & 3 \\
\hline Asymp. Sig. & 0.001 \\
\hline
\end{tabular}

Table 8: Chi-Square.

Of the Table 8, we find that: $0.001 \mathrm{sig}=$ less than $0.05=\alpha$ and Batalli reject the null hypothesis and accept the alternative hypothesis is the presence of the impact between the mother's education level and the awareness of parents of the importance of kindergarten.
Fifth: The study of the relationship between the importance of kindergartens and the idea of making kindergarten mandatory phase:

Null hypothesis H0: There is no relationship between the importance of kindergartens and the idea of making kindergarten mandatory stage.

Alternative H1: A relationship between the importance of kindergartens and the idea of making kindergarten mandatory stage.

In order to achieve this we use the simple to get the best regression equation describes the relationship between the dependent and independent variable regression.

\begin{tabular}{|l|l|l|l|l|}
\hline Model & $\mathbf{R}$ & R Square & $\begin{array}{l}\text { Adjusted } \\
\text { Square }\end{array}$ & $\begin{array}{l}\text { Std. Error of } \\
\text { the Estimate }\end{array}$ \\
\hline 1 & $0.650 a$ & 0.422 & 0.421 & 0.32603 \\
\hline
\end{tabular}

Table 9: Shows the correlation coefficient.

Table 9 shows that there is a strong correlation between the importance of kindergarten on child relationship in general and making kindergarten mandatory stage where the correlation coefficient (0.650). Appointment of appreciation Std. error. Error of the Estimate which is 0.32603 and indicates that he appreciated a small error in the model.

\begin{tabular}{|l|l|l|l|l|l|l|}
\hline \multicolumn{7}{|l|}{ ANOVA a } \\
\hline \multicolumn{2}{|l|}{ Model } & $\begin{array}{l}\text { Sum of } \\
\text { Square } \\
\text { s }\end{array}$ & df & $\begin{array}{l}\text { Mean } \\
\text { Square }\end{array}$ & F & Sig. \\
\hline \multirow{3}{*}{1} & Regression & 33.302 & 1 & 33.302 & 313.297 & $0.000 \mathrm{~b}$ \\
\cline { 2 - 8 } & Residual & 45.601 & 429 & 0.106 & & \\
\cline { 2 - 8 } & Total & 78.903 & 430 & & & \\
\hline
\end{tabular}

Table 10: Contains the results of analysis of variance ANOVA moral regression testing.

Table 10 shows sig $=0.000$ less than $\alpha=0.05$. This leads us to reject the null hypothesis and accept the alternative hypothesis which is a relationship between the importance of kindergartens and the idea of making kindergarten mandatory stage.

\begin{tabular}{|c|c|c|c|c|c|c|}
\hline \multicolumn{7}{|c|}{ Coefficients a } \\
\hline \multirow{2}{*}{\multicolumn{2}{|c|}{ Model }} & \multicolumn{2}{|c|}{$\begin{array}{l}\text { Unstandardized } \\
\text { Coefficients }\end{array}$} & \multirow{2}{*}{$\begin{array}{l}\begin{array}{l}\text { Standardize } \\
\text { d } \\
\text { Coefficients }\end{array} \\
\text { Beta }\end{array}$} & \multirow[t]{2}{*}{$\mathbf{t}$} & \multirow{2}{*}{ Sig. } \\
\hline & & B & $\begin{array}{l}\text { Std. } \\
\text { Error }\end{array}$ & & & \\
\hline \multirow[b]{2}{*}{1} & (Constant) & 2.659 & 0.088 & & 30.122 & 0 \\
\hline & $\begin{array}{l}\text { 4-Do you support } \\
\text { the idea of making } \\
\text { kindergarten } \\
\text { mandatory pre- } \\
\text { primary. }\end{array}$ & 0.348 & 0.02 & 0.65 & 17.7 & 0 \\
\hline & lent Variable: $\mathrm{T} 1$ & & & & & \\
\hline
\end{tabular}

Table 11: The regression liner coefficients. 
Citation: Badr MM, Gamdi SA, Hakeem S, Almansour A, Algamdi N, et al. (2016) The Impact of Nursery on Children in Terms of Learning and Social Behaviors (The Motivation for Learning and Social Behaviors after Joining the Primary Grades at the Elementary Level). Arts Social Sci J 7: 206. doi:10.4172/2151-6200.1000206

Page 8 of 9

Table 11 shows the estimated regression line error of judgment for each coefficient of the equation and that of Unstandardized Coefficients where the column $\mathrm{Y}=2.659+0.348$.

Regression equation to show that there is a proportional correlation between the idea of making kindergarten mandatory pre-primary and the importance of kindergarten on a child, as we can through the regression equation to predict the value of the variable $y$ where $(x$ making the idea of kindergarten mandatory stage) (y importance of kindergarten).

Sixth: To study the relationship between the awareness of locals phase kindergarten and kindergarten are essential for the beginning of a successful education to inflict a child in primary school:

\section{Assuming that:}

Null hypothesis H0: Lack of awareness of the relationship between the parents and the kindergarten stage kindergarten are essential to a successful start and necessary for the admission of the child to primary school.

Alternative H1: A relationship between people's awareness phase of kindergartens and kindergarten are essential to a successful start and necessary for the admission of the child to primary school.

In order to achieve this, we use multiple regressions to get the best regression equation represents the relationship between the dependent variable and two variables are independent.

\begin{tabular}{|l|l|l|l|l|}
\hline \multicolumn{5}{|c|}{ Model Summary } \\
\hline Model & R & R Square & $\begin{array}{l}\text { Adjusted R } \\
\text { Square }\end{array}$ & $\begin{array}{l}\text { Std. Error } \\
\text { of } \\
\text { Estimate }\end{array}$ \\
\hline 1 & $.789 a$ & 0.622 & 0.62 & 0.28768 \\
\hline
\end{tabular}

Table 12: Shows the correlation coefficient.

Table 12 shows that there is a strong correlation between the relationship (the awareness of parents kindergarten stage the first stages of the first rows step) and the independent variable (from your point of view kindergarten is necessary for the beginning of education and successful kindergarten necessary stage to join the child primary school), where the coefficient correlation (0.789).

\begin{tabular}{|l|l|l|l|l|l|l|}
\hline \multicolumn{7}{|l|}{ ANOVA a } \\
\hline \multicolumn{2}{|l|}{ Model } & $\begin{array}{l}\text { Sum of } \\
\text { Square } \\
\text { s }\end{array}$ & df & $\begin{array}{l}\text { Mean } \\
\text { Square }\end{array}$ & F & Sig. \\
\hline \multirow{3}{*}{1} & Regression & 58.327 & 2 & 29.164 & 352.379 & $.000 \mathrm{~b}$ \\
\cline { 2 - 8 } & Residual & 35.422 & 428 & 0.083 & & \\
\cline { 2 - 8 } & Total & 93.749 & 430 & & & \\
\hline
\end{tabular}

Table 13: Results of analysis of variance ANOVA moral regression testing.

From Table 13, we find that sig $=0.000$ less than $\alpha=0.05$ and therefore reject the null hypothesis and accept the alternative hypothesis is the presence of a relationship between the awareness of parents kindergarten stage and from your point of view kindergarten necessary and successful phase for enrollment of a child primary school.

\begin{tabular}{|c|c|c|c|c|c|c|}
\hline \multicolumn{7}{|c|}{ Coefficients a } \\
\hline \multirow{2}{*}{\multicolumn{2}{|c|}{ Model }} & \multicolumn{2}{|c|}{$\begin{array}{l}\text { Unstandardized } \\
\text { Coefficients }\end{array}$} & \multirow{2}{*}{\begin{tabular}{|l|}
$\begin{array}{l}\text { Standardize } \\
d \\
\text { Coefficients }\end{array}$ \\
Beta
\end{tabular}} & \multirow[t]{2}{*}{$t$} & \multirow{2}{*}{ Sig. } \\
\hline & & B & $\begin{array}{l}\text { Std. } \\
\text { Error }\end{array}$ & & & \\
\hline \multirow{3}{*}{1} & (Constant) & 1.559 & 0.12 & & 12.944 & 0 \\
\hline & $\begin{array}{l}\text { 2- From your point } \\
\text { of view } \\
\text { kindergarten stage } \\
\text { necessary for } \\
\text { admission to a } \\
\text { child in primary } \\
\text { school }\end{array}$ & 0.094 & 0.022 & 0.137 & 4.317 & 0 \\
\hline & $\begin{array}{l}\text { 3- From your point } \\
\text { of view Are the } \\
\text { kindergarten stage } \\
\text { necessary for the } \\
\text { beginning of a } \\
\text { successful } \\
\text { education for your } \\
\text { child }\end{array}$ & 0.56 & 0.024 & 0.73 & 23.019 & 0 \\
\hline \multicolumn{7}{|c|}{ a. Dependent Variable } \\
\hline
\end{tabular}

Table 14: Regression liner coefficients.

Table 14 shows the estimated regression line error of judgment for each coefficient of the equation and that of Substandard Coefficients where $\mathrm{a}=1.559, \mathrm{~b} 1=0.094, \mathrm{~b} 2=0.560$ column.

$$
\mathrm{Y}=1.559+0.094 \mathrm{X} 1+0.560 \mathrm{X} 2
$$

Regression equation to show that there is a strong proportional link between the need to enroll a child for kindergarten pre-primary and it's beginning to teach successful and a parents of the importance of kindergarten first stages of the primary grades as a step as we can through the regression equation to predict the value of the variable $y$ where $(x$, in your opinion stage kindergartens are necessary to enroll the child in school and kindergarten are essential for the beginning of a successful education for your child) ( $y$ awareness of parents of the importance of kindergarten as a first step).

\section{Recommendations}

- The adoption of the kindergarten stage of basic levels of education.

- Provide separation of at least a kindergarten and another preview in every elementary school.

- The imposition of English language teaching material from kindergarten, similar in Arabic.

- Rehabilitation of kindergarten teachers academically and psychologically to deal with the kids at this age.

- Provide special buildings for kindergarten equipped with modern means of safe spaces for the establishment of various activities.

- Reduce the number of students per classroom teacher so that they can focus on all students and their attention.

- Provision of a nurse and a psychologist to address the problems that might occur with a child.

- Not to transfer the child from kindergarten until perfected to the requirements of this stage. 
Citation: Badr MM, Gamdi SA, Hakeem S, Almansour A, Algamdi N, et al. (2016) The Impact of Nursery on Children in Terms of Learning and Social Behaviors (The Motivation for Learning and Social Behaviors after Joining the Primary Grades at the Elementary Level). Arts Social Sci J 7: 206. doi:10.4172/2151-6200.1000206

Page 9 of 9

- The development of kindergarten curriculum to suit the child's environment and modern methods of education.

- Preparation courses and workshops for teachers who have not kindergarten at khassn.

- Develop evaluation mechanism to ensure that children master the learning outcomes required of this stage.

- The presence of specialist heard and pronounces to detect weaknesses in the child and solved with the participation of the family.

- The separation of boys from girls in kindergarten taking into account the physical differences and differing favorite activities.

- The introduction of Light Qaeda essential approach in kindergarten.

\section{Discussion and Conclusion}

Composition of a private advisory panel to kindergarten at the Ministry of Education to develop the kindergarten curriculum and develop a flexible and comprehensive approach to unified and integrated fixed and includes the Arabic language and math, English, and employed in a variety of activities commensurate with the reconstruction of the children and their potential variation.

Assigning companies authored educational wrote outputs commensurate with the kindergarten stage in terms of containing the basics that a child learns at this stage (such as reading letters and words).
Educate residents of the importance of this stage and the consequent scientific establishment for the child making sure that there is communication between kindergarten teachers and parents.

\section{Acknowledgement}

This paper was funded by the KAU endowment (WAQF), King Abdulaziz University, Jeddah. The authors, therefore, acknowledge with thanks WAQF technical and financial support.

\section{References}

1. Ministry of Education (2013) Atfal. Journal of knowledge.

2. Taraf (2010) Education forum.

3. http://www.m0dy.net/vb/t466805.html

4. Hayatnafs (2010) Education in Kindergarten.

5. Qayimat A (2011) Umm Al Qura University.

6. Ahmed AA (2016) Manage and organize Kindergartens institutions.

7. http://www.hayatnafs.com/abnao2na/kindergardenteacher.htm

8. Khalifa I (2009) Comprehensive book in kindergarten. Dar curriculum.

9. http://kidsways.blogspot.in/p/blog-page.html? $\mathrm{m}=1$

10. Mohamed N (2007) SPSS Statistical analysis using SPSS.

11. Hafiz AR (2015) Fundamentals of scientific research.

12. Brown JD (2011) Fifth Likert Scale1.

13. Muhtawiat (2016) Kindergarten. 